\title{
Scientific Teaching and Active Learning yet to Revolutionize Education in East Asia
}

\author{
Justin Fendos ${ }^{1,2}$ \\ ${ }^{1}$ Tan School of Genetics, Fudan University, China \\ ${ }^{2}$ Global Biotechnology, Dongseo University, South Korea \\ Correspondence: Justin Fendos, Associate Director, Tan School of Genetics, Fudan University, China.
}

Received: October 3, 2017

doi:10.20849/aes.v2i4.210
Accepted: October 29, $2017 \quad$ Online Published: November 3, 2017

URL: https://doi.org/10.20849/aes.v2i4.210

\begin{abstract}
Science education in the United States has undergone a profound shift in emphasis away from lecture-based and knowledge-based approaches towards more hands-on platforms with emphasis on skill training and maximizing feedback. Of central importance in this movement has been the concept of scientific teaching: the idea of treating education like a scientific subject by performing experiments on educational outcomes. In the last two decades, a wealth of research has been conducted using this principle to examine the effectiveness of a wide range of pedagogical techniques. Of the many methods used to deliver class content to students, active learning has emerged as one of the most powerful. Another critical development in scientific teaching has been the realization of a wide range of standardized assessment tools for quantifying various student outcomes. Despite the convincing nature of empirical evidence in favor of the utility of both scientific teaching and active learning, dissemination of these platforms in average teaching practices has been slow, even in the US. This article reviews the many advances and challenges of scientific teaching reform, ending with a brief commentary of reform experiences in the US and how these may impact East Asia in the near future.
\end{abstract}

Keywords: scientific teaching, active learning, STEM education, authentic research experiences

\section{Introduction}

Dr. Donald Bligh was the first to experimentally verify that lectures are not particularly effective methods of learning (Bligh, 1985; Bligh, 1998). His findings were met at first with various degrees of skepticism (Wilson and Korn, 2007; Matheson, 2008) but continued work on assessments of educational outcome by a variety of authors has effectively confirmed lectures are not to be favored (McCarthy \& Anderson, 2000; Niemi, 2002; Armbruster, Patel, Johnson, \& Weiss, 2009). This lack of effectiveness is evident in knowledge learning (Laws, 1991; Sivan, Leung, Woon, \& Kember, 2000; Powell, 2003) but even more pronounced in skill learning (Hake, 2001; Handelsman, Houser \& Kriegel, 1997; Pukkila, 2004). This latter fact is of particular importance in the sciences because laboratory and science process skills are often considered the basic foundations of proper training (Roth \& Roychoudhury, 2003; Harlen, 1999; Padilla, 1990).

In lieu of this realization, science education in the United States has undergone a profound shift in emphasis away from lecture-based and knowledge-based approaches towards more hands-on approaches with emphasis on skill training and maximized feedback (Hofstein \& Lunetta, 2004; Alfieri, Brooks, Aldrich \& Tenenbaum, 2011). In 2004, a groundbreaking paper by Jo Handelsman and colleagues was published in Science, a work that identified the importance of treating education like a scientific subject by performing experiments on learning outcomes with carefully designed and quantifiable outputs to analyze (Handelsman et al, 2004; Miller, Pfund, Pribbenow \& Handelsman, 2008). This process of experimental treatment was coined in the title of their paper as scientific teaching.

Since 2004, a wealth of research has been conducted using the principles of scientific teaching to examine the effectiveness of a wide range of pedagogical techniques (Ebert-May \& Hodder, 2008; Pfund, 2009). Learning gains in discovery-based inquiry (Quitadamo, Faiola, Johnson, \& Kurtz, 2008; Reynolds \& Caperton, 2011), the advantages of group discussion formats (Osborne, 2010; Millis, 2010; Ferreri \& O'Connor, 2013), the strengths and weaknesses of technology use in the classroom (Hoffman \& Goodwin, 2006; Gauci, Dantas, Williams, \& Kemm, 2009; Pierce \& Fox, 2012), and the development of better techniques for reading primary literature 
(Hoskins, Lopatto, \& Stevens, 2011; Kozeracki, Carey, Colicelli, \& Levis-Fitzgerald, 2006) have been some of the many improvements and discoveries in STEM education. Various combinations of these efforts have begun to deliver widespread improvements in learning gains and student outcome in STEM education (Labov, Reid, \& Yamamoto, 2010; Udovic et al, 2002), as demonstrated in recent work published by Freeman and colleagues (Freeman et al, 2004).

\section{Advantages of Active Learning}

Of the many methods used to deliver class content to students, active learning has emerged as one of the most powerful (Petress, 2008; Machemer \& Crawford, 2007). Stated simply, active learning is a redesign of in-class activities to enhance student interactions and feedback through facilitated problem-solving activities (Ebert-May, Brewer, \& Allred, 1997; Taraban et al, 2007). These activities concentrate student and instructor time on the application of the knowledge they are learning, maximizing feedback between students and between instructors and students while also giving more practice of higher level skills (Bot, Gossiaux, Rauch, \& Tabiou, 2005).

The advantages and strengths of active learning have been well documented in recent years. Improved learning gains (Haak, HilleRisLambers, Pitre, \& Freeman, 2011; Freeman et al, 2011), higher student grades (Yoder, \& Hochevar, 2005; Armbruster et al, 2009), better retention of students (Braxton, Jones, Hirschy, \& Hartley, 2008; Crosling, Thomas, \& Heagney, 2008), and expanded levels of interest (Smith et al, 2009; Martyn, 2007) are some of the many advantages of a properly applied active learning system. One of the core principles of active learning is the concept of "reverse design" or a "flipped classroom" (Jensen, Kummer, \& Godoy, 2015; Stone, 2012; Bishop, \& Verleger, 2013). Both of these terms essentially refer to the same thing: a reorganization of the tasks students perform in-class as opposed to out-of-class. In a traditional lecture format, class content is delivered to students in the form of lectures. In science, out-of-class activities are usually dominated by problem sets that require students to apply the things they learned in lecture. The issue with this traditional format is that students rarely retain the things they are exposed to in lecture, severely reducing learning effectiveness and efficiency while putting a lot of pressure on students to develop problem solving skills on their own (Milman, 2012; Roehl, Reddy, \& Shannon, 2013).

In active learning, this traditional format is flipped or reversed. In active learning, the delivery of class content occurs outside of class, through readings or online lectures (Abeysekera \& Dawson, 2015; Tune, Sturek, \& Basile, 2013). Problem solving activities, on the other hand, become in-class elements. The main advantage of this format is that the more difficult of the two tasks now occurs in an environment with direct feedback from instructors and fellow students, allowing for better and faster learning (Auster \& Wylie, 2006; Armbruster et al, 2009). Another important advantage is the change in focus. In many respects, the ability to apply science knowledge is the ultimate goal of a successful education. Therefore, implementing a class format that better reflects this desired order of importance is essential: bringing problem-solving under the direct supervision of instructors so students can receive more and better feedback.

\section{The Power of Assessments}

In addition to improvements in class format, another critical development in scientific teaching has been the realization of a wide range of standardized assessment tools for quantifying various student outcomes (Stiggins \& Chappuis, 2005; Stiggins, Arter, Chappuis, \& Chappuis, 2004; Bennett, 2011). As mentioned above, tools to quantify knowledge retention (Heritage, Kim, Vendlinski, \& Herman, 2009; Shepard, 2005; Cox, Imrie, \& Miller, 2014) and skill competence (Griffin \& Care, 2014; Gormally, Brickman, \& Lutz, 2012; Dasgupta, Anderson, \& Pelaez, 2014) have been two of the most important in establishing the importance of a scientifically assessed approach to learning. The development of other assessments has also been very fruitful. Tools to gauge student attitudes about classes (Semsar, Knight, Birol, \& Smith, 2011; Preszler, Dawe, Shuster, \& Shuster, 2007), different learning methods (Valenta, Therriault, Dieter, \& Mrtek, 2001; Suanpang, Petocz, \& Kalceff, 2004), and group work dynamics (Hassanien, 2006; Orr, 2010; Zhang, Johnston, \& Kilic, 2008) have all been very helpful in identifying some of the challenges and barriers to better learning. One of the important conclusions drawn from this work is the surprising degree of variability in the way different students may respond differently to the same learning methods, with obvious consequences for more inclusive learning (Lage, Platt, \& Treglia, 2000; César \& Santos, 2006; Scott, Park, Swain-Bradway, \& Landers, 2007).

In some respects, the staggering expansion of new assessment tools, especially those yielding statistically significant results, has been one of the most important innovations brought about by scientific teaching (Yarime \& Tanaka, 2012; Shriberg, 2002). At present, the development of new assessment tools to measure skill competence are a major topic of interest in education research (Kogan, Holmboe, \& Hauer, 2009; Scalese, Obeso, $\&$ Issenberg, 2008). Tools for quantifying a student's ability to understand and apply genetics knowledge, for 
example, are devices with immense potential in helping instructors evaluate whether students are learning what is intended. Being able to make distinctions in this competence is equally important. Just because a student correctly describes what the law of independent assortment is does not guarantee she can apply that knowledge correctly to a balancer chromosome fly genetics problem.

One of the most important overall conclusions that has been drawn through the wealth of scientific teaching literature is that an explanation is not enough. Instructors are often lulled into the belief that having explained something once or twice should be sufficient for students to retain that information accurately (Tiwari, Lai, So, \& Yuen, 2006; Sinclair \& Ferguson, 2009). Scientific teaching research clearly demonstrates this is a misconception on the part of instructors. Instead, it appears that long-term retention of new information often requires students to apply that information in some way, often more than once, a goal that active learning is specifically designed to facilitate (Ebert-May, Brewer, \& Allred, 1997; Taraban et al, 2007). This requirement for additional exposure to obtain mastery of new knowledge is something presented in almost self-evident fashion in Bloom's pyramid, the conceptual model that organizes the six modes of human thinking into a hierarchy (Klymkowsky, Garvin-Doxas, \& Zeilik, 2003; Jeffries \& Huggett, 2014).

\section{Authentic Research Experiences}

For education in the STEM fields, classes are invariably separated into two basic types: lectures and labs. Most traditional lab courses are like a cookbook in the sense that everything is explained beforehand, with nothing new for students to discover (Brownell, Kloser, Fukami, \& Shavelson, 2012; Longo, 2011). This tendency runs contrary to the reasons why many students decide to major in science. Often, science majors are motivated by the desire to discover new things. The main place where this discovery takes place and where students anticipate it will take place in their academic careers is in lab classes. However, the cookbook format of most traditional labs often leaves students disappointed about the amount they learn or get to discover (Gooding \& Metz, 2012; Volkmann \& Abell, 2003).

In recent years, a number of universities including Yale and Stanford have begun developing new platforms for teaching lab classes with more potential to discover (Tomasik, Cottone, Heethuis, \& Mueller, 2013; Spell, Guinan, Miller, \& Beck, 2014). One of these platforms is the authentic research experience (ARE). AREs are lab courses structured around real research so that the tasks given to students provide the opportunity to discover something new. This type of discovery can be advantageous because it gives students the opportunity to practice many important research skills that they would otherwise not practice in a cookbook format (Cuthbert, Arunachalam, \& Licina, 2012; Edwards, Jones, Wapstra, \& Richardson, 2012; Makarevitch, Frechette, \& Wiatros, 2015). For example, AREs frequently gives students the chance to design their own hypotheses or make decisions about what reagents or conditions to use in their experiments. These decisions not only give students the opportunity to think about the experiments they are performing but they also afford the chance for students to have ownership, stimulating their desire to discover and learn through discovery.

If crafted correctly, AREs can be very powerful platforms for generating useful experimental results. At Fudan University, we have been operating a large-scale ARE called BIOS (BIOS Program, n.d.). BIOS is a summer ARE with six topical tracks: biochemistry, cell biology, fly genetics, fish genetics, mouse genetics, and plant biology. Students recruited into the program receive training in two topical areas over the course of eight weeks. Not only do some of the experiments the students perform give authentic results of scientific significance, the training regimen also results in competent students who can directly enter labs to whom those experimental results or methods are important. In this way, AREs can be coordinated with research labs to function as training centers for undergraduates wishing to work in a lab, directly addressing one of the common difficulties with preparing undergraduates for real research.

\section{Institutional Challenges to Scientific Teaching}

Despite the convincing nature of empirical evidence in favor of the utility of both scientific teaching and active learning, dissemination of these two platforms in average teaching practices has been slow, even in the US (Anderson et al, 2011). The first major issue has been awareness (Niemi, 2002). In the United States, the Howard Hughes Medical Institute (HHMI) and the National Academy of Sciences have been at the forefront of advocating for the virtues of scientific teaching. HHMI has been particularly aggressive in spending hundreds of millions of dollars on various types of training and the development of scientific teaching programs. The most significant of these investments has been the establishment of the "Summer Institutes on Scientific Teaching", a circuit of annual regional conferences designed to both train faculty and spread awareness of contemporary education research (Pfund et al, 2009).

Skepticism has remained another important challenge to overcome. The vast majority of faculty in any academic 
field have not only relied on lectures their entire lives but also seldom been exposed to the possibility of alternative teaching methods. This fact has created a general reluctance for established instructors to adjust their teaching. In a variety of contexts, younger faculty, postdoctoral fellows, and graduate students have generally been observed to be more willing to try new things but these transitions have also required systematic support in terms of training, feedback, and guidance as properly implemented scientific teaching and active learning platforms can often be quite sophisticated in their operation (Wieman, 2007). Even with these investments and efforts, the simple truth remains that the vast majority of teachers in the United States (postsecondary and otherwise) are still unaware of scientific teaching and its important advantages.

For research universities, the issue of awareness runs in parallel with the way in which faculty are recruited. In the vast majority of recruitments, heavy emphasis is paid on the value of the candidate's research. This frequently leaves teaching philosophy and experience as a secondary concern in the hiring process (Bush et al, 2006). The irony of this is not lost on some, who correctly point out that the majority of faculty salaries are still budgeted from income derived from student tuition. Yet, promotions and compensation for faculty usually still depend primarily on research outcomes, especially in the STEM fields. Aware of this issue, HHMI has devoted a lot of time and resources to incentivize better teaching through the implementation of systems relying more on scientific teaching and active learning (Prince, Felder, \& Brent, 2007).

\section{Addressing the Institutional Challenges}

One of the important spaces that HHMI has targeted with great success has been the process of graduate student and postdoctoral associate training (Boyle \& Boice, 1998; Nerad, 2004). Traditionally, this training process has focused almost exclusively on research, with the ultimate goal of publishing high impact papers in SCI journals. A typical science $\mathrm{PhD}$ program does require graduate students to teach two or more semesters worth of class yet that requirement seldom comes with an organized effort or curriculum to train students in good teaching techniques. It is in this space that HHMI and others have begun to make a difference by establishing basic training infrastructure for scientific teaching and active learning. Not only do these training programs give future faculty an earlier exposure to alternative teaching methods, they also allow for a culture change beginning from the roots up instead of top down (Austin \& McDaniels, 2006).

Another significant campaign for bringing more scientific teaching and active learning to classrooms has involved the establishment of faculty rosters exclusively dedicated to teaching. The University of Minnesota, Twin Cities, has been one of the universities at the forefront of this movement, creating "teaching professor" positions with faculty specifically dedicated to employing scientific teaching and active learning methods, usually in courses at the introductory level (Teaching Assistant Professor: Biology Teaching and Learning, n.d.). Through HHMI funding, the University of Minnesota has also established a number of training programs for postdoctoral associates to participate in these introductory courses, under the guidance of the teaching professors. Much like the basic notion behind AREs, this participation gives direct, hands-on experience in implementing scientific teaching and active learning designs with structured feedback (Labov, 2004). At Fudan University, the BIOS program is run in a very similar way with graduate students working alongside trained peers to practice and learn the active learning system (BIOS program, n.d.).

\section{Scientific Teaching outside the US}

Outside of the United States, the issues of awareness and reluctance are even more pronounced. In Europe, no centralized institution like HHMI has yet taken up the cause of scientific teaching. This has resulted in a serious lack of support and funding, perpetuating the lack of awareness. Although general knowledge about flipped classrooms and reverse design is present in many European countries, the vast majority of education research published about scientific teaching and active learning globally remains of American origin.

The situation in Asia is quite similar. Despite a general global reputation for excellence in science, East Asian countries such as China, Japan, and South Korea also exhibit very little awareness of scientific teaching and active learning. This is despite some recent awakening to the ideas of reverse design and a flipped classroom. Speaking anecdotally, one of the major issues with implementations of reverse design in Asia have been rooted in the lack of understanding that a flipped classroom is only one component in the larger platform of active learning. This has resulted in many situations where instructors unfamiliar with the basic aspects of scientific teaching and active learning have attempted to implement a flipped classroom in isolation, only to be disappointed with subpar learning outcomes or negative feedback from students.

\section{Transference Challenges in East Asia}

East Asian countries such as China, Japan, and South Korea are characterized by classroom cultures rooted to 
varying degrees in Confucian values. It is, therefore, important to consider how these values may potentially affect the implementation of new teaching systems. In terms of design, modern higher education systems in most East Asian countries share many common characteristics with western counterparts, often being modeled on these counterparts (Sung \& Lee, 2017). Despite these similarities, recent research has indicated that a Confucian classroom culture can result in significant differences in how classroom interactions occur (Shin, 2012). According to this research, two main characteristics distinguish such interactions in a Confucian classroom: a high level of instructor authority and a low level of student independence.

A quantitative measure for determining interpersonal interactions is nonverbal immediacy. Compared to US peers, recent research has shown that Korean teachers tend to exhibit much lower levels of nonverbal immediacy when interacting with students (Park et al., 2009). This is despite the fact that student satisfaction levels across a variety of academic settings have been shown to correlate positively with nonverbal immediacy (Pogue \& AhYun, 2006; Zhang, 2006; Jaasma \& Koper, 1999).

Other indications that Confucian and western classroom cultures are different have been published in recent work comparing the teaching strategies of Dutch and Korean instructors (van de Grift et al., 2017). This work shows Dutch teachers are more adept at "creating safe and stimulating" learning environments while Korean teachers are better at "teaching learning strategies". The second of these results is especially significant because it reflects the fact that Korean instructors are not only expected to convey knowledge but also expected to dictate the methods with which students should learn (Shin, 2012). On the face of it, this would suggest students in a Confucian classroom would be more accepting of alternative learning methods.

Despite being empowered with high levels of authority, Korean teachers also appear to suffer from "protective vulnerability" (Song, 2016), a condition characterized by the strong expectation that every teacher must be a master of their subject. This cultural circumstance is capable of imparting shame upon an instructor if he/she falls short of the expectation. Recent research has suggested teachers in Confucian classrooms may protect against this shame by actively or passively discouraging student questions and creativity, since these student excursions may reveal limitations in the teacher's knowledge (Song, 2016). In the active protective mode, teachers may openly admonish a student for challenging something they said, reinforcing the established social order. In the passive mode, teachers do not directly discourage students. Rather, an unspoken understanding prevails, sometimes enforced by senior students, through which it is assumed students should not question their teacher. Both modes function to protect the teacher from shame while significantly reducing the number of interactions students have with their teacher, likely impacting learning in negative ways by reducing feedback and cooperative activity.

Considering the process of implementing alternative pedagogical methods, a low level of student independence is likely to make the process easier on a classroom level since the students are already more accustomed to having the methods of learning dictated to them (Shin, 2012). At the same time, a high level of teacher authority is likely to reinforce entrenched skepticisms about new learning methods, decreasing the ability of student feedback to drive reform, in contrast to the situation in the US, where student feedback has and still plays a key role.

Culturally established hierarchies among teachers is another circumstance likely to impact the implementation of new teaching systems in a negative way. In such hierarchies, younger and less experienced teachers, who might be more amenable to the idea of education reform, are less likely to be able to exert influence through reform efforts if their designs run contrary to the expectations and conceptions of senior colleagues with more authority. This possibility again points to the need for a centralized authority to lead future reform efforts.

\section{Concluding Remarks}

Given the convincing nature of the virtues of scientific teaching and active learning, it would appear inevitable that these two platforms of learning eventually make their way into more science curricula globally. If events in the United States and the implications of a Confucian culture are to serve as any guide, one of the important steps is likely the establishment of an institutional push for reform. In the United States, this push has occurred predominantly through HHMI. In China, Fudan University is currently the only institution that has seriously taken up the challenge of adopting these newer teaching methods. As work through BIOS and other education initiatives becomes more widely known and publicized, we expect other institutions, both academic and government, to pay more attention to this changing trend in how science education is administered. At the end of the day, such reform will be most beneficial for our students.

\section{References}


Abeysekera, L., \& Dawson, P. (2015). Motivation and cognitive load in the flipped classroom: definition, rationale and a call for research. Higher Education Research \& Development, 34(1), 1-14. https://doi.org/10.1080/07294360.2014.934336

Alfieri, L., Brooks, P. J., Aldrich, N. J., \& Tenenbaum, H. R. (2011). Does discovery-based instruction enhance learning?. Journal of Educational Psychology, 103(1), 1-18. http://dx.doi.org/10.1037/a0021017.supp

Anderson, W. A., Banerjee, U., Drennan, C. L., Elgin, S. C. R., Epstein, I. R., Handelsman, J., ... Strobel, S. A. (2011). Changing the culture of science education at research universities. Science, 331(6014), 152-153. https://doi.org/10.1126/science.1198280

Armbruster, P., Patel, M., Johnson, E., \& Weiss, M. (2009). Active learning and student-centered pedagogy improve student attitudes and performance in introductory biology. CBE-Life Sciences Education, 8(3), 203-213. https://doi.org/10.1187/cbe.09-03-0025

Auster, E. R., \& Wylie, K. K. (2006). Creating active learning in the classroom: A systematic approach. Journal of Management Education, 30(2), 333-353. https://doi.org/10.1177/1052562905283346

Austin, A. E., \& McDaniels, M. (2006). Preparing the professoriate of the future: Graduate student socialization for faculty roles. HIGHER EDUCATION, 397-456. https://doi.org/10.1007/1-4020-4512-3_8

Bennett, R. E. (2011). Formative assessment: A critical review. Assessment in Education: Principles, Policy \& Practice, 18(1), 5-25. https://doi.org/10.1080/0969594X.2010.513678

BIOS Program (n.d.) Tan School of Genetics. Retrieved September 27, 2017 from http://tsi.fudan.edu.cn/students/undergraduate-students/bios/

Bishop, J. L., \& Verleger, M. A. (2013, June). The flipped classroom: A survey of the research. In ASEE National Conference Proceedings, Atlanta, GA, 30( 9), 1-18.

Bligh, D. (1985). What's the use of lectures?. Journal of Geography in Higher Education, 9(1), 105-106. https://doi.org/10.1080/03098268508708932

Bligh, D. A. (1998). What's the Use of Lectures?. Intellect books.

Bot, L., Gossiaux, P. B., Rauch, C. P., \& Tabiou, S. (2005). 'Learning by doing': a teaching method for active learning in scientific graduate education. European journal of engineering education, 30(1), 105-119. https://doi.org/10.1080/03043790512331313868

Boyle, P., \& Boice, B. (1998). Systematic mentoring for new faculty teachers and graduate teaching assistants. Innovative Higher Education, 22(3), 157-179. https://doi.org/10.1023/A:1025183225886

Braxton, J. M., Jones, W. A., Hirschy, A. S., \& Hartley III, H. V. (2008). The role of active learning in college student persistence. New Directions for Teaching and Learning, 2008(115), 71-83. https://doi.org/10.1002/t1.326

Brownell, S. E., Kloser, M. J., Fukami, T., \& Shavelson, R. (2012). Undergraduate biology lab courses: Comparing the impact of traditionally based" cookbook" and authentic research-based courses on student lab experiences. Journal of College Science Teaching, 41(4), 36.

Bush, S. D., Pelaez, N. J., Rudd, J. A., Stevens, M. T., Williams, K. S., Allen, D. E., \& Tanner, K. D. (2006). On hiring science faculty with education specialties for your science (not education) department. CBE-Life Sciences Education, 5(4), 297-305. https://doi.org/10.1187/cbe.06-09-0189

César, M., \& Santos, N. (2006). From exclusion to inclusion: Collaborative work contributions to more inclusive learning settings. European Journal of Psychology of Education, 21(3), 333-346. https://doi.org/10.1007/BF03173420

Cox, K., Imrie, B. W., \& Miller, A. (2014). Student assessment in higher education: a handbook for assessing performance. Routledge.

Crosling, G., Thomas, L., \& Heagney, M. (2008). Improving student retention in higher education: the role of teaching and learning. Routledge.

Cuthbert, D., Arunachalam, D., \& Licina, D. (2012). 'It feels more important than other classes I have done': an 'authentic'undergraduate research experience in sociology. Studies in Higher Education, 37(2), 129-142. https://doi.org/10.1080/03075079.2010.538473

Dasgupta, A. P., Anderson, T. R., \& Pelaez, N. (2014). Development and validation of a rubric for diagnosing students' experimental design knowledge and difficulties. CBE-Life Sciences Education, 13(2), 265-284. 
https://doi.org/10.1187/cbe.13-09-0192

Ebert-May, D., \& Hodder, J. (Eds.). (2008). Pathways to scientific teaching. Sunderland, Massachusetts, USA: Sinauer Associates.

Ebert-May, D., Brewer, C., \& Allred, S. (1997). Innovation in large lectures: Teaching for active learning. Bioscience, 47(9), 601-607. https://doi.org/10.2307/1313166

Edwards, A., Jones, S. M., Wapstra, E., \& Richardson, A. M. (2012, October). Engaging students through authentic research experiences. In Proceedings of the Australian Conference on Science and Mathematics Education (Formerly UniServe Science Conference).

Ferreri, S. P., \& O'Connor, S. K. (2013). Redesign of a large lecture course into a small-group learning course. American journal of pharmaceutical education, 77(1), 13. https://doi.org/10.5688/ajpe77113

Freeman, S., Eddy, S. L., McDonough, M., Smith, M. K., Okoroafor, N., Jordt, H., \& Wenderoth, M. P. (2014). Active learning increases student performance in science, engineering, and mathematics. Proceedings of the National Academy of Sciences, 111(23), 8410-8415. https://doi.org/10.1073/pnas.1319030111

Gauci, S. A., Dantas, A. M., Williams, D. A., \& Kemm, R. E. (2009). Promoting student-centered active learning in lectures with a personal response system. Advances in Physiology Education, 33(1), 60-71. https://doi.org/10.1152/advan.00109.2007

Gooding, J., \& Metz, B. (2012). Folding inquiry into cookbook lab activities. Science Scope, 35(8), 42-47.

Gormally, C., Brickman, P., \& Lutz, M. (2012). Developing a test of scientific literacy skills (TOSLS): measuring undergraduates' evaluation of scientific information and arguments. CBE-Life Sciences Education, 11(4), 364-377. https://doi.org/10.1187/cbe.12-03-0026

Griffin, P., \& Care, E. (Eds.) (2014). Assessment and teaching of 21st century skills: Methods and approach. Springer.

Haak, D. C., HilleRisLambers, J., Pitre, E., \& Freeman, S. (2011). Increased structure and active learning reduce the achievement gap in introductory biology. Science, 332(6034), 1213-1216. https://doi.org/10.1126/science. 1204820

Hake, R. R. (2001). Lessons from the physics-education reform effort. arXiv preprint physics/0106087.

Handelsman, J., Ebert-May, D., Beichner, R., Bruns, P., Chang, A., DeHaan, R., ... Wood, W. B. (2004). Scientific teaching. Science, 304(5670), 521-522. https://doi.org/10.1126/science.1096022

Handelsman, J., Houser, B., \& Kriegel, H. (1997). Biology brought to life: a guidebook to teaching students to think like scientists. McGraw-Hill Primis.

Harlen, W. (1999). Purposes and procedures for assessing science process skills. Assessment in Education: Principles, Policy \& Practice, 6(1), 129-144. https://doi.org/10.1080/09695949993044

Hassanien, A. (2006). Student experience of group work and group assessment in higher education. Journal of Teaching in Travel \& Tourism, 6(1), 17-39. https://doi.org/10.1300/J172v06n01_02

Heritage, M., Kim, J., Vendlinski, T., \& Herman, J. (2009). From evidence to action: A seamless process in formative assessment?. Educational Measurement: Issues and Practice, 28(3), 24-31. https://doi.org/10.1111/j.1745-3992.2009.00151.x

Hoffman, C., \& Goodwin, S. (2006). A clicker for your thoughts: Technology for active learning. New Library World, 107(9/10), 422-433. https://doi.org/10.1108/03074800610702606

Hofstein, A., \& Lunetta, V. N. (2004). The laboratory in science education: Foundations for the twenty - first century. Science Education, 88(1), 28-54. https://doi.org/10.1002/sce.10106

Hoskins, S. G., Lopatto, D., \& Stevens, L. M. (2011). The CREATE approach to primary literature shifts undergraduates' self-assessed ability to read and analyze journal articles, attitudes about science, and

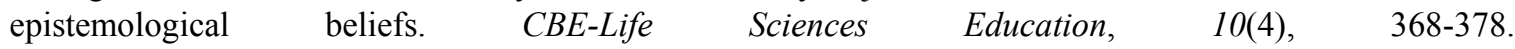
https://doi.org/10.1187/cbe.11-03-0027

Jaasma, M. A., \& Koper, R. J. (1999). The relationship of student - faculty out - of - class communication to instructor immediacy and trust and to student motivation. Communication Education, 48(1), 41-47. https://doi.org/10.1080/03634529909379151

Jeffries, W. B., \& Huggett, K. N. (2014). Flipping the classroom. In An introduction to medical teaching (pp. 
41-55). Springer Netherlands. https://doi.org/10.1007/978-94-017-9066-6_4

Jensen, J. L., Kummer, T. A., \& Godoy, P. D. D. M. (2015). Improvements from a flipped classroom may simply be the fruits of active learning. CBE-Life Sciences Education, 14(1), ar5. https://doi.org/10.1187/cbe.14-08-0129

Klymkowsky, M. W., Garvin-Doxas, K., \& Zeilik, M. (2003). Bioliteracy and teaching efficacy: what biologists can learn from physicists. Cell Biology Education, 2(3), 155-161. https://doi.org/10.1187/cbe.03-03-0014

Kogan, J. R., Holmboe, E. S., \& Hauer, K. E. (2009). Tools for direct observation and assessment of clinical skills of medical trainees: a systematic review. Jama, 302(12), 1316-1326. https://doi.org/10.1001/jama.2009.1365

Kozeracki, C. A., Carey, M. F., Colicelli, J., \& Levis-Fitzgerald, M. (2006). An intensive primary-literaturebased teaching program directly benefits undergraduate science majors and facilitates their transition to doctoral programs. CBE-Life Sciences Education, 5(4), 340-347. https://doi.org/10.1187/cbe.06-02-0144

Labov, J. B. (2004). From the National Academies: the challenges and opportunities for improving undergraduate science education through introductory courses. Cell Biology Education, 3(4), 212-214. https://doi.org/10.1187/cbe.04-07-0049

Labov, J. B., Reid, A. H., \& Yamamoto, K. R. (2010). Integrated biology and undergraduate science education: a new biology education for the twenty-first century?. CBE-Life Sciences Education, 9(1), 10-16. https://doi.org/10.1187/cbe.09-12-0092

Lage, M. J., Platt, G. J., \& Treglia, M. (2000). Inverting the classroom: A gateway to creating an inclusive learning environment. The Journal of Economic Education, 31(1), 30-43. https://doi.org/10.1080/00220480009596759

Laws, P. W. (1991). Calculus-based physics without lectures. Physics today, 44(12), 24-31. https://doi.org/10.1063/1.881276

Longo, C. M. (2011). Designing inquiry-oriented science lab activities: Teachers can create inquiry-oriented science lab activities that make real-world connections. Middle School Journal, 43(1), 6-15. https://doi.org/10.1080/00940771.2011.11461788

Machemer, P. L., \& Crawford, P. (2007). Student perceptions of active learning in a large cross-disciplinary classroom. Active Learning in Higher Education, 8(1), 9-30. https://doi.org/10.1177/1469787407074008

Makarevitch, I., Frechette, C., \& Wiatros, N. (2015). Authentic research experience and "big data" analysis in the classroom: maize response to abiotic stress. CBE-Life Sciences Education, 14(3), ar27. https://doi.org/10.1187/cbe.15-04-0081

Martyn, M. (2007). Clickers in the classroom: An active learning approach. Educause Quarterly, 30(2), 71.

Matheson, C. (2008). The educational value and effectiveness of lectures. The Clinical Teacher, 5(4), 218-221. https://doi.org/10.1111/j.1743-498X.2008.00238.x

McCarthy, J. P., \& Anderson, L. (2000). Active learning techniques versus traditional teaching styles: Two experiments from history and political science. Innovative Higher Education, 24(4), 279-294. https://doi.org/10.1023/B:IHIE.0000047415.48495.05

Miller, S., Pfund, C., Pribbenow, C. M., \& Handelsman, J. (2008). Scientific teaching in practice. Science, 322(5906), 1329-1330. https://doi.org/10.1126/science.1166032

Millis, B. J. (2010). Why faculty should adopt cooperative learning approaches. Cooperative Learning in Higher Education: Across the Disciplines, across the Academy, 10.

Milman, N. B. (2012). The flipped classroom strategy: What is it and how can it best be used? Distance Learning, 9(3), 85.

Nerad, M. (2004). The PhD in the US: Criticisms, facts, and remedies. Higher Education Policy, 17(2), 183-199. https://doi.org/10.1057/palgrave.hep.8300050

Niemi, H. (2002). Active learning - a cultural change needed in teacher education and schools. Teaching and Teacher Education, 18(7), 763-780. https://doi.org/10.1016/S0742-051X(02)00042-2

Orr, S. (2010). Collaborating or fighting for the marks? Students' experiences of group work assessment in the creative arts. Assessment \& Evaluation in Higher Education, 35(3), 301-313. https://doi.org/10.1080/02602931003632357 
Osborne, J. (2010). Arguing to learn in science: The role of collaborative, critical discourse. Science, 328(5977), 463-466. https://doi.org/10.1126/science.1183944

Padilla, M. J. (1990). The science process skills. Research Matters-to the science Teacher, 9004.

Park, H. S., Lee, S. A., Yun, D., \& Kim, W. (2009). The impact of instructor decision authority and verbal and nonverbal immediacy on Korean student satisfaction in the US and South Korea. Communication Education, 58(2), 189-212. https://doi.org/10.1080/03634520802450531

Petress, K. (2008). What is meant by "Active Learning?". Education, 128(4), 566-570.

Pfund, C., Miller, S., Brenner, K., Bruns, P., Chang, A., Ebert-May, D., ... Labov, J. B. (2009). Summer institute to improve university science teaching. Science, 324(5926), 470-471. https://doi.org/10.1126/science.1170015

Pierce, R., \& Fox, J. (2012). Vodcasts and active-learning exercises in a "flipped classroom" model of a renal pharmacotherapy module. American Journal of Pharmaceutical Education, 76(10), 196. https://doi.org/10.5688/ajpe7610196

Pogue, L. L., \& AhYun, K. (2006). The effect of teacher nonverbal immediacy and credibility on student motivation and affective learning. Communication Education, 55(3), 331-344. https://doi.org/10.1080/03634520600748623

Powell, K. (2003). Science education: spare me the lecture. Nature, 425(6955), 234-236. https://doi.org/10.1038/425234a

Preszler, R. W., Dawe, A., Shuster, C. B., \& Shuster, M. (2007). Assessment of the effects of student response systems on student learning and attitudes over a broad range of biology courses. CBE-Life Sciences Education, 6(1), 29-41. https://doi.org/10.1187/cbe.06-09-0190

Prince, M. J., Felder, R. M., \& Brent, R. (2007). Does faculty research improve undergraduate teaching? An analysis of existing and potential synergies. Journal of Engineering Education, 96(4), 283-294. https://doi.org/10.1002/j.2168-9830.2007.tb00939.x

Pukkila, P. J. (2004). Introducing student inquiry in large introductory genetics classes. Genetics, 166(1), 11-18. https://doi.org/10.1534/genetics.166.1.11

Quitadamo, I. J., Faiola, C. L., Johnson, J. E., \& Kurtz, M. J. (2008). Community-based inquiry improves critical thinking in general education biology. CBE-Life Sciences Education, 7(3), 327-337. https://doi.org/10.1187/cbe.07-11-0097

Reynolds, R., \& Caperton, I. H. (2011). Contrasts in student engagement, meaning-making, dislikes, and challenges in a discovery-based program of game design learning. Educational Technology Research and Development, 59(2), 267-289. https://doi.org/10.1007/s11423-011-9191-8

Roehl, A., Reddy, S. L., \& Shannon, G. J. (2013). The flipped classroom: An opportunity to engage millennial students through active learning. Journal of Family and Consumer Sciences, 105(2), 44. https://doi.org/10.14307/JFCS105.2.12

Roth, W. M., \& Roychoudhury, A. (1993). The development of science process skills in authentic contexts. Journal of Research in Science Teaching, 30(2), 127-152. https://doi.org/10.1002/tea.3660300203

Scalese, R. J., Obeso, V. T., \& Issenberg, S. B. (2008). Simulation technology for skills training and competency assessment in medical education. Journal of general internal medicine, 23(1), 46-49. https://doi.org/10.1007/s11606-007-0283-4

Scott, T. M., Park, K. L., Swain-Bradway, J., \& Landers, E. (2007). Positive behavior support in the classroom: Facilitating behaviorally inclusive learning environments. International Journal of Behavioral Consultation and Therapy, 3(2), 223. https://doi.org/10.1037/h0100800

Semsar, K., Knight, J. K., Birol, G., \& Smith, M. K. (2011). The Colorado learning attitudes about science survey (CLASS) for use in biology. CBE-life Sciences Education, 10(3), 268-278. https://doi.org/10.1187/cbe.10-10-0133

Shepard, L. A. (2005). Linking Formative Assessment to Scaffolding. Educational Leadership, 63(3), 66-70.

Shin, J. C. (2012). Higher education development in Korea: Western university ideas, Confucian tradition, and economic development. Higher Education, 64(1), 59-72. https://doi.org/10.1007/s10734-011-9480-5

Shriberg, M. (2002). Institutional assessment tools for sustainability in higher education: strengths, weaknesses, 
and implications for practice and theory. International Journal of Sustainability in Higher Education, 3(3), 254-270. https://doi.org/10.1108/14676370210434714

Sinclair, B., \& Ferguson, K. (2009). Integrating simulated teaching/learning strategies in undergraduate nursing education. International Journal of Nursing Education Scholarship, 6(1). https://doi.org/10.2202/1548-923X.1676

Sivan, A., Leung, R. W., Woon, C. C., \& Kember, D. (2000). An implementation of active learning and its effect on the quality of student learning. Innovations in Education and Teaching International, 37(4), 381-389. https://doi.org/10.1080/135580000750052991

Smith, M. K., Wood, W. B., Adams, W. K., Wieman, C., Knight, J. K., Guild, N., \& Su, T. T. (2009). Why peer discussion improves student performance on in-class concept questions. Science, 323(5910), 122-124. https://doi.org/10.1126/science. 1165919

Song, J. (2016). Emotions and Language Teacher Identity: Conflicts, Vulnerability, and Transformation. TESOL Quarterly, 50(3), 631-654. https://doi.org/10.1002/tesq.312

Spell, R. M., Guinan, J. A., Miller, K. R., \& Beck, C. W. (2014). Redefining authentic research experiences in introductory biology laboratories and barriers to their implementation. CBE-Life Sciences Education, 13(1), 102-110. https://doi.org/10.1187/cbe.13-08-0169

Stiggins, R. J., Arter, J. A., Chappuis, J., \& Chappuis, S. (2004). Classroom assessment for student learning: doing it right--using it well. Assessment Training Institute.

Stiggins, R., \& Chappuis, J. (2005). Using student-involved classroom assessment to close achievement gaps. Theory into practice, 44(1), 11-18. https://doi.org/10.1207/s15430421tip4401_3

Stone, B. B. (2012). Flip your classroom to increase active learning and student engagement. In Proceedings from 28th Annual Conference on Distance Teaching \& Learning, Madison, Wisconsin, USA.

Suanpang, P., Petocz, P., \& Kalceff, W. (2004). Student attitudes to learning business statistics: Comparison of online and traditional methods. Journal of Educational Technology \& Society, 7(3).

Sung, Y. K., \& Lee, Y. (2017). Is the United States losing its status as a reference point for educational policy in the age of global comparison? The case of South Korea. Oxford Review of Education, 43(2), 162-179. https://doi.org/10.1080/03054985.2016.1257424

Taraban, R., Box, C., Myers, R., Pollard, R., \& Bowen, C. W. (2007). Effects of active - learning experiences on achievement, attitudes, and behaviors in high school biology. Journal of research in science teaching, 44(7), 960-979. https://doi.org/10.1002/tea.20183

Teaching Assistant Professor: Biology Teaching and Learning. (n.d). University of Minnesota, Twin Cities, College of Biological Sciences. Retrieved September 27, 2017 from https://cbs.umn.edu/research/faculty-hiring/btlasstprof

Tiwari, A., Lai, P., So, M., \& Yuen, K. (2006). A comparison of the effects of problem - based learning and lecturing on the development of students' critical thinking. Medical education, 40(6), 547-554. https://doi.org/10.1111/j.1365-2929.2006.02481.x

Tomasik, J. H., Cottone, K. E., Heethuis, M. T., \& Mueller, A. (2013). Development and preliminary impacts of the implementation of an authentic research-Based experiment in General Chemistry. Journal of Chemical Education, 90(9), 1155-1161. https://doi.org/10.1021/ed300328p

Tune, J. D., Sturek, M., \& Basile, D. P. (2013). Flipped classroom model improves graduate student performance in cardiovascular, respiratory, and renal physiology. Advances in Physiology Education, 37(4), 316-320. https://doi.org/10.1152/advan.00091.2013

Udovic, D., Morris, D., Dickman, A., Postlethwait, J., \& Wetherwax, P. (2002). Workshop biology: demonstrating the effectiveness of active learning in an introductory biology course. AIBS Bulletin, 52(3), 272-281. https://doi.org/10.1641/0006-3568(2002)052[0272:WBDTEO]2.0.CO;2

Valenta, A., Therriault, D., Dieter, M., \& Mrtek, R. (2001). Identifying student attitudes and learning styles in distance education. Journal of Asynchronous Learning Networks, 5(2), 111-127.

van de Grift, W. J., Chun, S., Maulana, R., Lee, O., \& Helms-Lorenz, M. (2017). Measuring teaching quality and student engagement in South Korea and The Netherlands. School Effectiveness and School Improvement, 28(3), 337-349. https://doi.org/10.1080/09243453.2016.1263215 
Volkmann, M. J., \& Abell, S. K. (2003). Rethinking laboratories. The Science Teacher, 70(6), 38.

Wieman, C. (2007). Why not try a scientific approach to science education?. Change: The Magazine of Higher Learning, 39(5), 9-15. https://doi.org/10.3200/CHNG.39.5.9-15

Wilson, K., \& Korn, J. H. (2007). Attention during lectures: Beyond ten minutes. Teaching of Psychology, 34(2), 85-89. https://doi.org/10.1177/009862830703400202

Yarime, M., \& Tanaka, Y. (2012). The issues and methodologies in sustainability assessment tools for higher education institutions: a review of recent trends and future challenges. Journal of Education for Sustainable Development, 6(1), 63-77. https://doi.org/10.1177/097340821100600113

Yoder, J. D., \& Hochevar, C. M. (2005). Encouraging active learning can improve students' performance on examinations. Teaching of Psychology, 32(2), 91-95. https://doi.org/10.1207/s15328023top3202_2

Zhang, B., Johnston, L., \& Kilic, G. B. (2008). Assessing the reliability of self - and peer rating in student group work. Assessment \& Evaluation in Higher Education, 33(3), 329-340. https://doi.org/10.1080/02602930701293181

\section{Copyrights}

Copyright for this article is retained by the author(s), with first publication rights granted to the journal.

This is an open-access article distributed under the terms and conditions of the Creative Commons Attribution license (http://creativecommons.org/licenses/by/4.0/). 